\title{
Firma Değeri Yaratımında Marka Gücünün Etkisi: Interbrand İndirgenmiş Nakit Akışı Yöntemiyle Türk Markalarının Analizi
}

\author{
Adnan KARA*
}

ÖZ

Araştırmanın amacı Türk markalarının değerlerinin hesaplanmasında marka gücünün ve bu markaların toplam satış hasılatları içerisinde markalı ürünlerinden elde ettikleri gelirlerin rolünün belirlenmesidir. Araştırma hem finansal hem de tüketici yönlü bakış açılarını olanaklı kılan karma hesaplama yöntemlerinden Interbrand marka değerleme yöntemiyle, Türk markalarının analizlerini kapsamaktadır. Araştırmanın uygulama kısmında, BrandFinance 2017 Türkiye'nin en değerli markaları sıralamasında yer alan; Türk Telekom, Turkcell, Türk Hava Yolları ve Arçelik incelenmiştir. Araştırma sonucunda değerlerine göre markalar sıralanmış ve bu sıralamaya göre Türk Telekom birinci, Turkcell ikinci, Arçelik üçüncü en değerli markalar olarak belirlenmiştir. Interbrand marka değerleme yöntemi ile en değerli Türk markalarının değerlendirilmesinin literatürde önemli bir boşluğu dolduracağı düşünülmektedir.

Anahtar Kelimeler: Marka Değerleme, Firma Finansal Analiz, EVA, Marka Gücü, Talep Analizi

JEL Sinıflandırması: G17, M39, D46

\section{The Effect of Brand Equity on Firm Valuation: Analysis of Turkish Brands with Interbrand Discounted Cash Flow Method}

\begin{abstract}
The aim of the study is to determine the role of brand equity in the calculation of the values of Turkish brands and the role of these brands from their branded products in total sales revenue. The research covers the analysis of Turkish brands through Interbrand brand valuation method, which is one of the mixed calculation methods that enables both financial and consumer oriented perspectives. In the application part of the study, from the Brand Finance 2017 ranking list of Turkey's most valuable brands; Turk Telekom, Turkcell, Turkish Airlines and Arcelik were examined. At the end of the research, the brands were listed according to their values and according to this ranking, Turk Telekom was determined as the first, Turkcell as the second and Arcelik as the third most valuable brands. The evaluation of the most valuable Turkish brands with Interbrand brand valuation method is considered to fill an important gap in the literature.
\end{abstract}

Keywords: Brand Valuation, Firm Financial Analysis, EVA, Brand Power, Demand Analysis

JEL Classification: G17, M39, D46

Geliş Tarihi / Received: 21.11.2018 Kabul Tarihi / Accepted: 23.01.2019

\footnotetext{
* Dr. Öğr. Üyesi, Bayburt Üniversitesi, İIBB, İşletme Bölümü, adnankara@bayburt.edu.tr, ORCID: 0000-0002-90450392.
} 


\section{GİRIŞ}

Günümüzde firma değerini belirleyen soyut varlıkların değişen pazar dinamikleriyle birlikte somut varlıkların önüne geçtikleri görülmektedir. İşletmelerin soyut varlıkları; entelektüel sermaye, araştırma geliştirmeyle sağlanan yenilikler ve tasarım kabiliyeti gibi somut olarak değer biçilemeyen kaynaklarıdır (Zambon ve Monciardini, 2015). Her ne kadar somut bir değer atfedilmesi güç olsa da, bunlar, firmaların değerini artıran ve marka gücünü oluşturan varlıklar olarak kabul edilmektedir. Bu türden soyut varlıklara sahip firmalar genellikle rakiplerine karşı pazar koşullarını belirleme konusunda üstün durumdadırlar. Buna ek olarak; soyut varlıklar ile desteklenen marka gücü, firma için aynı zamanda sadık müşteriler, ortalamadan daha yüksek ürün fiyatı ve pazar payı anlamına gelmektedir. Buradan hareketle, soyut varlıkların firma değerini artıran oldukça önemli unsurlar olduğu söylenebilir.

Türkiye'de muhasebe sistemi açısından markaların değerlemeye tabi tutulması zorunluluğu bulunmamaktadır. Buna neden olarak marka değerlemesinin muhasebeleştirilmesinde öznelliklerin olması gösterilebilir. Bu öznellikler, markanın tek başına getirdiği kazançların belirlenmesindeki güçlükler, gelecekte yaratacağı satışların öngörülmesindeki yanlılık ve yanılma olasılıkları gibi durumlar olarak sayılabilir. Buna rağmen Türk markalarının firma içi raporlamada ve markaya yapılacak yatırımlarda yol gösterici nitelikte değerlemeye tabi tutulması önemli görülmektedir. Türk markaları hâlihazırda birçok marka değerleme yöntemini kullanarak incelenebilir. Türk markalarının Interbrand yöntemi ile hesaplanması gerekliliği bu yöntemin ekonomik hesapları katmasının yanı sıra tüketici görüşlerini de göz önünde bulundurması ve popüler bir yöntem olmasındandır. Bu çalışmada Interbrand yöntemi Türkiye'de uygulanmakta olan muhasebe sistemi tek düzen hesap planındaki verilere göre nasıl uygulanabileceğinin gösterilmiştir. Böylelikle marka değerleme alanında Türk markalarının hesaplanmasını inceleyecek araştırmacılara yol göstermesi düşünülmektedir.

Öte yandan marka değerlemesi ise marka satın alımlarında işletmelerin rasyonel karar vermelerinde büyük öneme sahip stratejik bir araçtır. Marka değerlemesi ile satın alınması planlanan markanın gerçek değeri hesaplanabilmekte ve böylece işletmenin marka için ödemeye razı olduğu meblağın uygunluğu belirlenmektedir. Genellikle markanın gerçek değeri ifadesi ile bir marka isminin pazarda yarattığı etkinin finansal karşıllğı vurgulanmaktadır. Güncel araştırmayla Türk markalarının değerlerinin hesaplanmasında marka gücünün rolünün belirlenmesi amaçlanmıştır. Böylelikle marka değerlemesi literatürüne önemli bir katkı sunulması hedeflenmiştir. Araştırma üç bölümden oluşmaktadır. Birinci bölümde, konunun kavramsal arka planı; marka değerleme yöntemleri açısından ele alınmıştır. İkinci bölümde, araştırma yöntemi ve marka değerleme uygulaması açıklanmıştır. Üçüncü bölümde ve son bölümde ise, marka değerlemeye ilişkin bulgulara yer verilerek en değerli markalar sıralanmıştır. Daha sonra bulgular yorumlanarak gelecek çalışmalar için önerilerde bulunulmuştur.

\section{KAVRAMSAL ARKA PLAN}

\subsection{Marka Değerleme}

İşletme varlıkları işletmenin sahip olduğu ve gelecekte nakit akışı sağlayabileceği ekonomik kaynaklardır. Marka da işletmenin varlıklarından biridir. Marka, pazarlamacılar açısından bir girdi olarak tüketicilere zihinsel imaj oluşturma ve finansçılar açısından bir çıktı olarak kurumlara değer oluşturma çabasıdır. Genel olarak marka, kurumların insanlara vaat ettiği eşsiz ve tatmin edici deneyimi sağlamak için kullandığ 1 işlevsel ve duygusal değerler kümesidir (Chernatony, McDonald ve Wallace, 2011). Markalar isim, sembol ve hatta tasarım şeklinde bile olabilirler. 
Marka değeri ve marka denkliği çoğu durumda birbirinin yerine kullanılan terimlerdir. Marka gücü olarak da ifade edilen marka denkliği işletmenin soyut varlıklarındandır ve markanın müşteri için anlamıdır. Marka denkliği, aynı pazarlama çabaları sonucunda bir markanın yapamadığını benzer başka bir markanın yapması durumunda ortaya çıkan pazarlama etkisi olarak tanımlanmaktadır (Keller, 1993). Örneğin benzer nitelikteki ürünler arasında birinin diğerine göre fiyatının yüksek olmasına rağmen konumunun değişmemesidir. Diğer bir ifadeyle yüksek fiyatlı olmasına karşın müşterilerin markaya sadık kalmasıdır. Marka değeri ise, katlanılan maliyetten somut ürün özellikleri ve soyut marka özelliklerinin toplamı çıkarıldıktan sonra elde edilen faydalardır (Wasserman, 2015). Bu nedenle marka değerleme işletmenin ürünü üretmek için kullandığı araştırma geliştirme, üretim, dağıtım gibi işletme kaynaklarının ve güçlü pazar konumu anlamına gelen marka denkliği ve büyüme potansiyeli gibi faktörlerin hesaplanmasidir.

\subsection{Marka Değerleme Yöntemleri}

Marka değerleme yöntemleri temelde pazarlama yönlü ve finans yönlü olmak üzere ikiye ayrılmaktadır (Christodoulides ve Chernatony, 2010). Finans yönlü yöntemler genellikle firmanın gelecekteki satışlarını temel almaktadırlar. Pazarlama yönlü yöntemler ise, pazar konumu ve tüketici görüşlerini de marka değerlemesi hesabına katmaktadırlar. Genellikle araştırma şirketleri tarafından geliştirilen marka değerleme yöntemleri, hem finans hem de pazarlama yönlüdür.

Marka değerlemenin yaklaşık 20 yıllık bir geçmişi olsa da yöntem geliştirme bakımından hızlı gelişen bir alandır. 1995'te marka değerlemede beş şirket bulunmaktayken günümüzde en az 39 marka değerleme yöntemi bulunmaktadır (Salinas, 2009). Marka değerleme uygulamacıları ve yazarları şu şekilde sınıflandırılabilir:

- Marka danışma ve pazarlama şirketleri (BDDO, Brand Rating, Interbrand, FutureBrand)

- Pazar araştırma şirketleri (Nielsen, Millward Brown, GfK)

- Maddi olmayan varlıkları değerleme şirketleri (AUS Consultants, Brand Finance, Intangible Business, vb.)

- Entelektüel varlık yönetim şirketleri

- Denetim şirketleri (Deloitte, PwC, E\&Y, KPMG)

- Akademisyenler (Lev, Damodaran, Sattler, vb.)

Uygulamacıların çoğunluğu birden fazla yöntemi kullanmaktadır. Değerleme yapılan markaya veya koşullara göre uyguladıkları yöntem değişebilmektedir. Maddi olmayan varlığın gerçek değerini ortaya koyabilmek için hangi yöntem uygun olursa o kullanılmaktadır. Aşağıdaki tabloda araştırma şirketleri tarafindan geliştirilen marka değerleme yöntemleri ve ele aldıkları marka gücü boyutları görülmektedir. 
Tablo 1: Marka Değerleme Modelleri

\begin{tabular}{ll}
\hline \multicolumn{1}{c}{ İsim } & \multicolumn{1}{c}{ Ölçek } \\
İnterbrand marka gücü & $\begin{array}{l}\text { Pazar, istikrar, marka liderliği, trend, marka desteği, } \\
\text { çeşitlendirme, koruma. }\end{array}$ \\
\hline Young \&Rubicom BrandAsset ${ }^{\circledR}$ Valuator & Bilgi, saygı, ilgi, farklılaştırma. \\
\hline WPP Millward BrandDynamics ${ }^{\mathrm{TM}}$ & Varlık, ilgi, performans, avantaj, ilişkilendirme. \\
\hline Uluslararası araştırma Equity EngineSM & $\begin{array}{l}\text { İlgi, algılanan fonksiyonel performans, markanın özkaynakları ve } \\
\text { fiyatı arasındaki etkileşim. }\end{array}$ \\
\hline Ipsos Grup Equity Builder & Farklılaşma, alaka düzeyi, popülerlik, kalite ve aşinalık. \\
AC Nielsen Winning Brands ${ }^{\mathrm{TM}}$ & Farkındalık, göz önüne alma, ürünün üç özelliği. \\
\hline BrandFinance Brand Strength Score & $\begin{array}{l}\text { Farkındalık / tanışılık, göz önüne alma, tercih-yeğleme, } \\
\text { memnuniyet, tavsiye. }\end{array}$ \\
\hline
\end{tabular}

Kaynak: Chernatony (2010).

Araştırma şirketlerinin geliştirdikleri marka gücü endeksleri marka değerlemesini etkileyen faktörler olarak modellenmektedir. Yukarıda marka değerleme modellerinde marka denkliği için kullanılan ölçekler genel olarak markanın pazardaki bilinirliği, liderliği, markanın şirket içinde ne kadar desteklendiği, nasıl ilişkilendirildiği, fonksiyonel performansı ve fiyat/değer karşılaştırmalarını içermektedir. Marka denkliği ölçekleri şirketler tarafından daha doğru değerlendirme için sürekli geliştirilmektedir. Aşağıda akademik çevre tarafından önerilen kavramsal modeller bulunmaktadır.

\section{Tablo 2: Marka Değerleme Kavramsal Modelleri}

\begin{tabular}{cl}
\hline Çalışma & \multicolumn{1}{c}{ Boyutları } \\
Aaker (1991, 1996) & Marka bilinirliği, marka birlikleri, algılanan kalite, marka sadakati \\
Blackston (1992) & Marka ilişkisi (marka ile güven, müşteri memnuniyeti) \\
Keller (1993) & Marka bilgisi (marka bilinirliği, marka çağrışımları) \\
Sharp (1995) & Şirket / marka bilinirliği, marka imajı, müşterilerle ilişkileri \\
Berry (2000) & Marka bilinirliği, marka anlamı \\
Burmann ve diğ. & $\begin{array}{l}\text { Marka fayda netliği, alğılanan marka kalitesi, marka fayda benzersizliği, } \\
\text { marka sempati, marka güveni }\end{array}$
\end{tabular}

Kaynak: Chernatony (2010).

Marka değerlemesinin hesaplanmasında kullanılan ve akademik çevre tarafından önerilen bazı kavramsal modeller bulunmaktadır. En bilinenlerden birincisi Aaker (1991) 
tarafından önerilen marka sadakati, isim farkındalığı, algılanan kalite, algılanan kaliteyle ilgili marka çağrışımlanı, diğer marka varlıkları (patentler, isim hakları, kanal ilişkileri) faktörlerinden oluşan marka denkliği kavramıdır. İkincisi ise, Keller (1993)'in marka denkliğinden etkilendiğini öne sürdüğü marka bilgisi modelidir. $\mathrm{Bu}$ modele göre marka bilgisi, marka farkındalığı (hatırlama, tanıma) ve marka imajı (marka çağrışımları)'ndan oluşmaktadır. Ayrıca markaya güven (Blackston, 1992) ve markayla duygusal bağ (Berry, 2000; Burmann vd., 2009) da marka denkliğinin kavramsal modellerinde etkileyici faktörler olarak değerlendirilmektedir. Marka değerleme modellerindeki eğilimler markaya yönelik tüketici tutumlarının belirlenmesine yöneliktir. Bunun yanı sıra markayla ilgili tüketici davranışlarının belirlenmesi de akademisyenlerin eğilimlerindendir.

$\mathrm{Bu}$ çalışmada Interbrand tarafindan geliştirilen marka gücü boyutları ele alınmıştır. Bunlar, liderlik, istikrar, coğrafi yayılım, pazarlama desteği, korunma, pazar, trenddir. Liderlik pazarı etkileme gücü, istikrar tüketicinin sadakati, coğrafi yayılım - uluslararası pazarlara yayılma derecesi, pazarlama desteği - firma içinden markalaşmaya yatırımı, korunma - markanın telif haklarına sahipliği, pazar - markanın bulunduğu pazardaki talep yapısındaki değişimleri, trend - markanın tüketiciler için uzun dönemli anlamıdır. Interbrand yöntemi akademik çalışmalardaki tüketici tutumları ve davranışlarını belirlemek üzerine olan eğilimlerin her ikisini de içermektedir. $\mathrm{Bu}$ nedenle geçerliliği kabul edilebilir modellerden birisidir. Marka değerlemesinin Türkiye'deki ampirik çalışmaları aşağıdaki tabloda gösterilmektedir.

Tablo 3: Türkiye’de Pazarlama Yönlü Marka Değerleme Ampirik Çalışmalar

\begin{tabular}{|c|c|c|c|c|}
\hline Ölçek & Boyutları & Ölçüm Düzeyi & Örneklem & Ürün Kategorisi \\
\hline $\begin{array}{l}\text { Koçak ve diğ. } \\
\text { (2007) }\end{array}$ & $\begin{array}{c}\text { Ürün fonksiyonel faydası, ürün } \\
\text { sembolik faydası, marka ismi } \\
\text { fonksiyonel faydası, marka ismi } \\
\text { sembolik faydası }\end{array}$ & $\begin{array}{l}\text { Bir marka } \\
\text { düzeyinde }\end{array}$ & Türkiye & Spor ayakkabıları \\
\hline Aydın (2009) & $\begin{array}{l}\text { Marka Aşinalı̆̆ı, Marka sadakati, } \\
\text { Algılanan Kalite, Markaya olan tutum, } \\
\text { Marka satın alma niyeti, Marka } \\
\text { Tecrübesi, Markayı kullanma durumu }\end{array}$ & $\begin{array}{l}\text { Değerlerine göre } \\
\text { markaların } \\
\text { siralamas1 }\end{array}$ & $\begin{array}{l}\text { Türkiye, } \\
\text { İstanbul }\end{array}$ & 28 farklı firma \\
\hline $\begin{array}{l}\text { Pinar ve diğ. } \\
\quad(2012)\end{array}$ & $\begin{array}{l}\text { Marka bilinirliği, algılanan kalite, } \\
\text { marka imajı, marka çağrışımı, kurum } \\
\text { çağrışımı ve marka sadakati }\end{array}$ & $\begin{array}{l}\text { Değerlerine göre } \\
\text { markaların } \\
\text { sıralaması }\end{array}$ & $\begin{array}{l}\text { Türkiye, } \\
\text { Ankara }\end{array}$ & Banka \\
\hline Özsevinç (2013) & $\begin{array}{l}\text { Satın alma isteği, farklılaşma, istikrar, } \\
\text { aile markası, ilginçlik, liderlik, yüksek } \\
\text { mertebe, ilgilenim, komünal duygular, } \\
\text { genel memnuniyet, ün, bölümmüş } \\
\text { bağlılık, yenilikçilik, sözel iletişim }\end{array}$ & $\begin{array}{l}\text { Değerlerine göre } \\
\text { markaların } \\
\text { sıralaması }\end{array}$ & Türkiye & $\begin{array}{l}\text { Şarkıc1, Doktor, } \\
\text { Politikacı }\end{array}$ \\
\hline Koca (2015) & $\begin{array}{l}\text { Marka farkındalığı, çağrışımlar, } \\
\text { algılanan kalite, sadakat }\end{array}$ & $\begin{array}{l}\text { Bir marka } \\
\text { düzeyinde }\end{array}$ & Türkiye & Basketbol takımı \\
\hline $\begin{array}{l}\text { Zengin ve } \\
\text { Güngördü (2015) }\end{array}$ & $\begin{array}{c}\text { Marka sadakati, marka imajı ve } \\
\text { algılanan kalite, insan, marka } \\
\text { farkındalığ } 1\end{array}$ & $\begin{array}{l}\text { Değerlerine göre } \\
\text { markaların } \\
\text { siralamas1 }\end{array}$ & $\begin{array}{l}\text { Türkiye, } \\
\text { Ankara }\end{array}$ & $\begin{array}{l}\text { Perakende } \\
\text { mağaza }\end{array}$ \\
\hline
\end{tabular}

Kaynak: Yazar tarafindan oluşturulmuştur. 
Akademik yazında marka değerlemeyle ilgili çok sayıda ampirik çalışma bulunmaktadır. Bu çalışmanın uygulaması Türk markalarını kapsadığından dolayı Türkiye'deki pazarlama yönlü marka değerleme ampirik çalışmalar incelenmiştir. Türkiye'deki çalışmalar incelendiğinde genel olarak bilinirlik, sadakat, çağrışımlar ve algılanan kalite üzerinden marka değerlemelerinin yapıldığı görülmektedir. Çalışmalarda çoğunlukla Aaker ve Keller’in modelleri kullanılmaktadır. Genel olarak aynı sektördeki farklı firmalar ya da tek bir marka incelenerek marka değerleri belirlenmeye çalışılmıştır. Türk markalarının incelendiği bu çalışma genel kabul gören bir modelin uygulanmasını göstermesinden ve farklı sektörlerdeki firmaların marka değerlemelerini göstermesinden dolayı akademik yazındaki bir boşluğu dolduracağı düşünülmektedir.

\section{YÖNTEM}

\subsection{Araştırmanın Amacı}

Araştırmanın amacı markanın değerinin hesaplanmasında, marka gücünün ve markalı ürünlerin toplam satışlar içindeki oranının öneminin belirlenmesidir. Interbrand indirgenmiş nakit akış yönteminden elde edilen modelde; birinci olarak, marka gücü endeks kriterlerine göre marka değerine firmanın pazarlama kabiliyetlerini yansıtan skorunun etkisinin belirlenmesi amaçlanmıştır. İkinci olarak, marka değeri ve markalı ürünlerden elde edilen gelirlere (faaliyet gelirleri / satış gelirleri) göre hesaplanan iskonto oranı arasındaki bağlantının incelenmesi amaçlanmıştır.

\subsection{Araştırmanın Yöntemi}

Araştırmada Türk markalarının değerleri Interbrand nakit akış yöntemiyle analiz edilmiştir. Araştırmanın uygulama kısmı BrandFinance tarafından yapılan 2017 yılı Türkiye'nin en değerli markalarından seçilen ilk dört markadır. Bunlar sırasıyla; Türk Telekom, Turkcell, Türk Hava Yolları, Arçelik'tir.

\subsection{Interbrand İndirgenmiş Nakit Akış Yöntemi}

$\mathrm{Bu}$ çalışmada marka değerlemesinde Interbrand indirgenmiş nakit akış yöntemi kullanılmıştır. Bu yöntemin seçilme nedeni hem daha nesnel olması hem de yaygın kabul görmesidir. Interbrand yöntemine göre marka değerlemesi yapılırken şu üç aşama yerine getirilir; 1) Markanın Net Şimdiki Değeri (Bunu bulmak için ekonomik katma değer yöntemi kullanılır) bulunur, 2) Marka Etki Endeksi - markanın nakit akışlarına ulaşmadaki rolünü ölçer hesaplanır, 3) Marka Gücü (liderlik, istikrar, pazarlama desteği, coğrafi yayılım, trend, pazar ve korunma) belirlenir. 


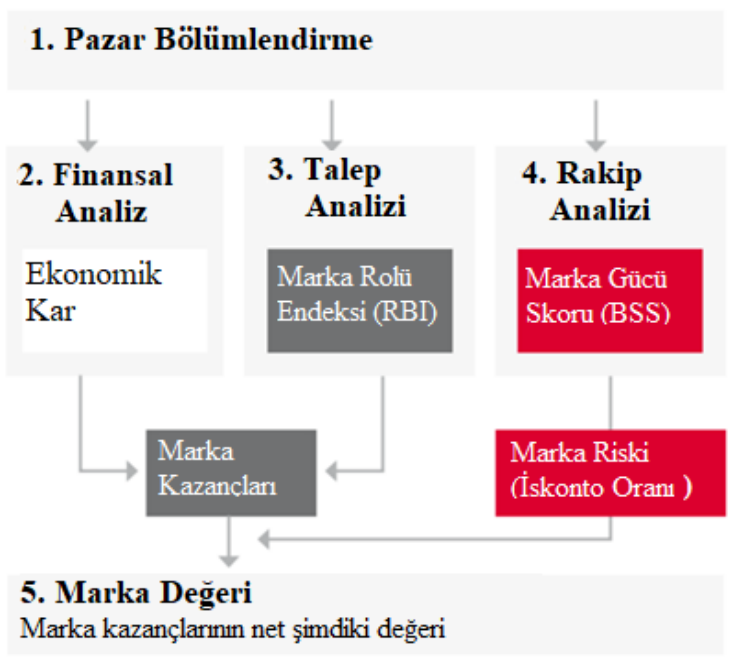

Şekil 1: Interbrand Marka Değerleme Modeli

Kaynak: https://www.interbrand.com/wp-content/uploads/2015/10/Interbrand-Financial-Applications-for-BrandValuations.pdf, Erişim: 14.11.2018.

Interbrand modeli üç aşamada gerçekleştirilir. Öncelikle, finansal analiz ile faaliyet gelirlerinden borçlar ve borçlanma maliyeti düşülerek ekonomik kar hesaplanmaktadır. Ekonomik katma değer, Akyüz (2013)'ün oluşturduğu ekonomik katma değer modeline uygun şekilde hesaplanmıştır. Ekonomik katma değer yöntemi aşağıdaki formüle göre hesaplanmıştır:

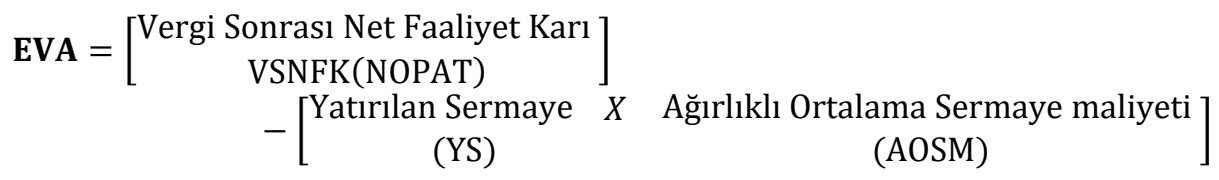

Yatırlan Sermaye = Dönem Başı Net İşletme Sermayesi + Duran Varlıklar

Net Işletme Sermayesi = Dönen Varlıklar - Kısa Vadeli Borçlar

AOSM $=($ Borçların Oranı + Borçların Vergi Sonrası Maliyeti $)+(\ddot{O} z$ Sermayenin Oranı x Öz Sermayenin Maliyeti)

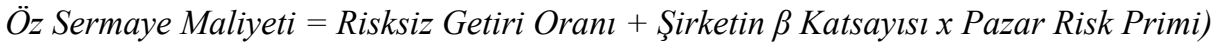

Borçlanma Maliyeti $=($ FVÖK $/$ Finansman Gideri $)+$ Spread

Yukarıdaki formülde pazar risk primi \%5 (şirketin bulunduğu sektörün getiri riskini ifade eder), risksiz faiz oranı on yıllık devlet tahvillerinin faiz oranına eşit varsayılmıştır. Şirketin ödeme gücüne denk gelen ek faiz (spread) değeri Hatipoğlu (2011) çalışmasında yer alan tablodaki karşılaştırma kullanılarak her bir şirket için kredi notuna göre karşıllğ̆ verilmiştir.

İkinci olarak, pazar analizi ile marka rolü endeksi bulunmaktadır. Marka rolü endeksi çeşitli endüstrilerde farklılaşmaktadır ve maddi olmayan gelirlerden markalı ürünlerin katkısının çıkarılmasıyla bulunmaktadır. Marka rolü endeksi (RBI), Interbrand indirgenmiş nakit akım yöntemine göre tüketicilere anket yapılarak değerlendirilmektedir. Ancak bu çalışmada marka rolü endeksinin belirlenmesinde Barth ve diğ. (1998)'nin Financial World kaynağını alıntı gösterdiği formülle markalı ürünlerin satışından elde edilen gelirlerin toplam satış gelirlerine oranının bulunmasıyla hesaplanan faaliyet marjı kullanılmıştır. Faaliyet marjı aşağıdaki formüle göre hesaplanmıştır. 


$$
\text { Faaliyet marjı }=\frac{\text { faaliyet } \text { karı }}{\text { satış gelirleri }}
$$

Üçüncü ve son olarak marka gücü hesaplanmaktadır. Marka gücü hesaplanırken yedi kritere göre derecelendirme yapılmaktadır. Marka gücü 100 puan üstünden hesaplanmaktadır ve sırasıly pazar \%25'lik, istikrar \%15'lik, liderlik \%10'lik, pazarlama desteği \%25'lik, trend \%10’luk, coğrafi yayılım \%10'luk, korunma \%10'luk etkiye sahiptir. Derecelendirmede 0-25 aras1 zayıf, 25-75 arası orta, 75-100 arası güçlü markaları ifade etmektedir. Marka gücü endeksinin belirlenmesinde uzmanlara aşağıdaki tabloda verilen sorular sorulmaktadır.

\section{Tablo 4: Marka Gücü Skoru Kriterleri}

\begin{tabular}{|c|c|c|}
\hline Kriter & Açıklama & Maksimum Skor \\
\hline Liderlik & Marka pazarında fiyat belirlemede lider mi? & 25 \\
\hline İstikrar & $\begin{array}{l}\text { Markaya sadakat bulunmakta mıdır? Marka istikrarlı bir } \\
\text { Pazar payına sahip midir? }\end{array}$ & 15 \\
\hline Coğrafi Yayılım & Markanın uluslararası kabullenilme düzeyi nedir? & 25 \\
\hline Pazarlama Desteği & $\begin{array}{l}\text { Markaya firma tarafından aktif olarak tutundurma } \\
\text { çalışması ve destek yapılmakta mıdır? }\end{array}$ & 10 \\
\hline Korunma & Marka telif haklarıyla yeterince korunmakta mıdır? & 5 \\
\hline Pazar & Markanın işlem gördüğü pazar istikrarlı mıdır? & 10 \\
\hline \multirow[t]{2}{*}{ Trend } & Markanın uzun dönemli geleceği nasıldır? & 10 \\
\hline & Toplam & 100 \\
\hline
\end{tabular}

Marka gücü hesaplanmasında her bir kriter için verilen skorlar toplanmaktadır. Daha sonra elde edilen 0-100 arasındaki marka skorundan bir dönüşüm fonksiyonu ile iskonto oranı belirlenmektedir. İskonto oranı markanın gelecekte mevcut durumunu koruyabilmesi ve markaya olası olumsuz etkileri yönetebilme kabiliyetiyle ile ilgili bir yüzdesel ifadedir. Marka değerinden risk karşılığ 1 olarak bu oran düşülmektedir. Aşağıdaki şekilde her bir marka skoruna karşıllk gelen iskonto oranı görülmektedir. 


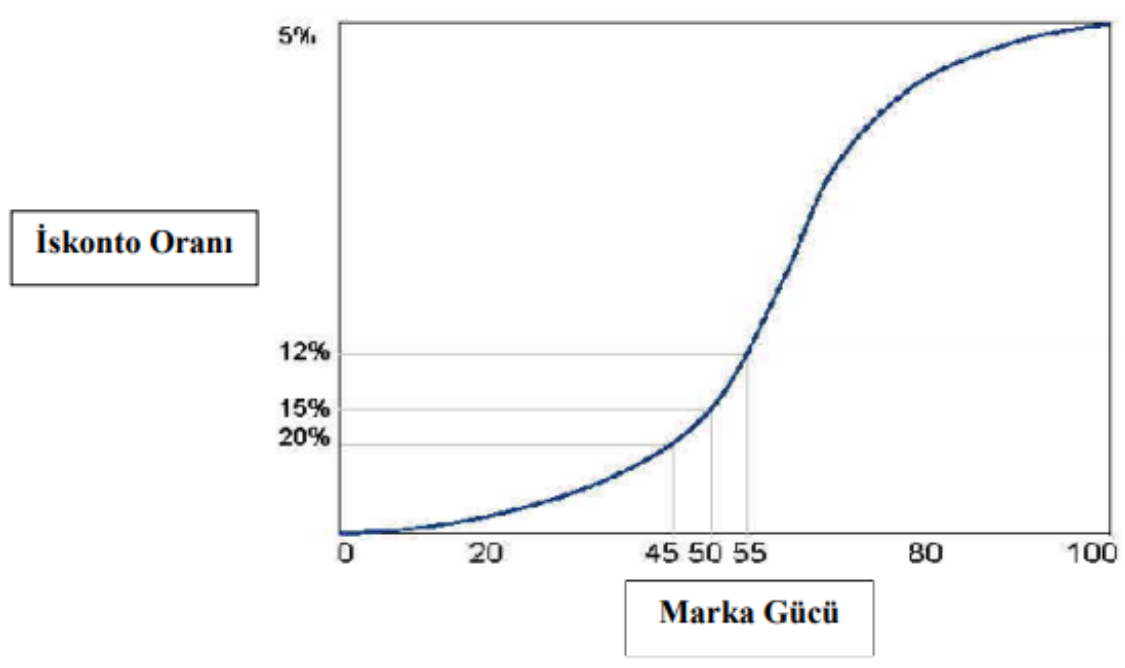

Şekil 2: Interbrand S Eğrisi

Kaynak: Kaya (2002).

Son olarak marka değeri şu formülle hesaplanmaktadır (Karataş, 2014):

$$
\sum \frac{\left(E V A_{i} * R B I\right)}{(1+r)^{i}}
$$

EVA: Vergi sonrası net faaliyet karından sermaye maliyetinin çıkarılması

RBI: Marka rolü endeksi

r: İskonto oranı

i: Y11 say1s1 (5)

$\mathrm{Bu}$ çalışmada yukarıdaki formül yardımıyla sırasıyla ekonomik katma değer ve marka rolü endeksi hesaplanmıştır. Daha sonra uzmanlık alanı pazarlama olan deneyimli dört akademisyenden her bir marka için yedi kriter çerçevesinde marka gücü skorunu oluşturması istenmiştir. Son olarak her bir marka için bulgular kısmında yer alan tablolar çıkarılarak marka değeri hesaplaması yapılmıştır. Marka değerlemelerinin hesaplanmasına ilişkin bulgular aşağıda verilmiştir.

\section{BULGULAR}

\subsection{Marka Değeri Hesaplamaları}

\subsubsection{Türk Telekom}

Türk Telekom; 1994 yılında PTT’ye bağlı bir birim olarak kurulmuştur, 1995 yılında hisseleri Türkiye Cumhuriyeti Başbakanlık Hazine Müsteşarlığı'na ait ayrı bir kurum haline gelmiş ve 2005 y1lında \%55 hissesi Oger Ortak Girişim Grubu'na özelleştirme yoluyla devredilmiştir. 2018 yılında şirketin \%55 hissesi Levent Yapılandırma yönetimi A.Ş.'ye devredilmiştir. Şirketin hisselerinin \%25'i T.C. Hazine ve Maliye Bakanlığı'nda, \%5'i Türkiye Varlık Fonu'nda ve \%15'i de halka arz edilmiş durumdadır. Şirket internet, telefon ve TV ürün ve hizmetleriyle 2016 yılı itibariyle 'Türk Telekom' tek marka çatısı altında çalışmaktadır (www.turktelekom.com.tr). 
Tablo 5: Türk Telekom EVA ve Marka Rolü Hesaplaması (TL)*

\begin{tabular}{|c|c|c|c|c|c|}
\hline & 2013 & 2014 & 2015 & 2016 & 2017 \\
\hline $\begin{array}{c}\text { Net Faaliyet Kârı } \\
\text { (FVÖK) }\end{array}$ & 3.014 .653 .000 & 2.827.749.000 & 2.865.599.000 & 2.591 .752 .000 & 3.406.197.000 \\
\hline $\begin{array}{c}\text { Vergi -20\% } \\
\text { (Düzeltilmiş Vergi) }\end{array}$ & 602.930 .600 & 565.549 .800 & 573.119 .800 & 518.350 .400 & 681.239 .400 \\
\hline VSNFK (NOPAT) & 2.411 .722 .400 & 2.262 .199 .200 & 2.292.479.200 & 2.073 .401 .600 & 2.724 .957 .600 \\
\hline Dönen Varlıklar & 4.849 .061 .000 & 6.413 .004 .000 & 8.441 .600 .000 & 9.186 .483 .000 & 10.566 .394 .000 \\
\hline $\begin{array}{l}\text { Kısa Vadeli } \\
\text { Yükümlülük }\end{array}$ & 5.052 .639 .000 & 4.225 .718 .000 & 8.552 .927 .000 & 8.351 .705 .000 & 8.661 .581 .000 \\
\hline $\begin{array}{l}\text { Uzun Vadeli } \\
\text { Yükümlülük }\end{array}$ & 5.052 .639 .000 & 4.225.718.000 & 12.227 .609 .000 & 15.136 .125 .000 & 15.931 .867 .000 \\
\hline Borçlar Toplamı & 10.105 .278 .000 & 8.451 .436 .000 & 20.780 .536 .000 & 23.487 .830 .000 & 24.593 .448 .000 \\
\hline Özsermaye & 5.327 .609 .000 & 6.303 .340 .000 & 4.993 .368 .000 & 3.386 .621 .000 & 4.555.087.000 \\
\hline Pasif Toplamı & 18.244 .515 .000 & 19.877.787.000 & 25.773.904.000 & 26.874 .451 .000 & 29.148.535.000 \\
\hline Borçların Ağırlığı(wi) & 0,553880331 & 0,425169864 & 0,806262645 & 0,873983621 & 0,843728441 \\
\hline $\begin{array}{c}\text { Borcun Vergiden } \\
\text { Sonraki Maliyeti (ki) }\end{array}$ & 0,1069 & 0,123325 & 0,123838462 & 0,141416667 & 0,132483333 \\
\hline$w i * k i$ & 0,059209807 & 0,052434074 & 0,099846325 & 0,12359585 & 0,111779956 \\
\hline $\begin{array}{l}\text { Özsermaye Ăğırlığı } \\
\text { (we) }\end{array}$ & 0,292011544 & 0,317104716 & 0,193737355 & 0,126016379 & 0,156271559 \\
\hline $\begin{array}{c}\text { Özsermaye Maliyeti } \\
\text { (ke) }\end{array}$ & 0,08212 & 0,09131 & 0,091823462 & 0,099401667 & 0,107968333 \\
\hline we*ke & 0,023979988 & 0,028954832 & 0,017789635 & 0,012526238 & 0,01687238 \\
\hline AOSM & 0,083189795 & 0,081388905 & 0,11763596 & 0,136122089 & 0,128652336 \\
\hline Net İşletme Sermayesi & -203578000 & 2187286000 & -111327000 & 834778000 & 1904813000 \\
\hline Duran Varlıklar & 13.395.454.000 & 13.464 .783 .000 & 17.332.304.000 & 17.638.934.000 & 18.582 .141 .000 \\
\hline Yatırılan Sermaye & 13.191 .876 .000 & 15.652 .069 .000 & 17.220.977.000 & 18.473 .712 .000 & 20.486 .954 .000 \\
\hline $\begin{array}{l}\text { Sermaye Maliyeti } \\
(\text { YS*AOSM) }\end{array}$ & 1082382677 & 1073672344 & 1841246164 & 2344155355 & 2376686205 \\
\hline $\begin{array}{c}\text { Ekonomik Katma } \\
\text { Değer (EVA) }\end{array}$ & 1.329 .339 .723 & 1.188 .526 .856 & 451.233 .036 & -270.753 .755 & 348.271 .395 \\
\hline Satış gelirleri & 13.116.958.000 & 13.601 .623 .000 & 14.522 .855 .000 & 16.108.594.000 & 18.139.554.000 \\
\hline Faaliyet Karı & 3.031 .546 .000 & 2.880 .281 .000 & 3.039 .488 .000 & 2.139.984.000 & 3.156 .350 .000 \\
\hline Marka Rolü (RBI)** & $23,11 \%$ & $21,18 \%$ & $20,93 \%$ & $13,28 \%$ & $17,40 \%$ \\
\hline EVA*RBI & 307232402,5 & 251682561,8 & 94438551,98 & $-35968918,48$ & 60600520,75 \\
\hline
\end{tabular}

* Tablodaki şirket bilanço ve gelirlerine ait veriler Kamuyu Aydınlatma Platformu'ndan alınmıştır.

** Faaliyet Karı/Satış Gelirleri 
Aşağıdaki tabloda Türk Telekom'un yedi kriter çerçevesinde değerlendirilen ve toplamı verilen marka gücü skorları görülmektedir.

Tablo 6: Türk Telekom Marka Gücü Skoru

\begin{tabular}{ccccccc}
\hline Liderlik & İstikrar & $\begin{array}{c}\text { Coğrafi } \\
\text { Yayılım }\end{array}$ & $\begin{array}{c}\text { Pazarlama } \\
\text { Desteği }\end{array}$ & Korunma & Pazar & Trend \\
$\mathbf{1 5 , 7 5}$ & 10 & 15 & 8,75 & 4,5 & 9 & 8,25 \\
& & Ískonto Orant $-\boldsymbol{r}: \mathbf{6 \%}$ & & Toplam & 71.25 \\
\hline
\end{tabular}

Not: Marka gücü skorları anket yoluyla elde edilen veriler ile toplanmıştır.

Yukarıdaki tablodaki değerlerden elde edilen toplam marka gücü skoru 71.25 'tir. $\mathrm{Bu}$ marka gücü skoruna karşılık gelen iskonto oranı $\% 6$ 'dır.

\subsubsection{Turkcell}

Turkcell, 1994 yılında kurulmuş Türkiye'nin ilk mobil iletişim şirketidir. Müşterilerine mobil ve sabit şebekeleri üzerinden ses, data, TV hizmetleri ve katma değerli bireysel ve kurumsal servisler sunmaktadır. Hisseleri 11 Temmuz 2000'de Borsa İstanbul (BİST) ve New York Stock Exchange'de (NYSE) eşzamanlı olarak işlem görmeye başlayan Turkcell, NYSE'ye kote olan tek Türk şirketi unvanına sahiptir. Turkcell aynı zamanda Borsa İstanbul Sürdürülebilirlik Endeksi’nde yer almaktadır.

Turkcell'in yurt dışında da yatırımları bulunmaktadır. 1999 yılında hizmete giren \%100 Turkcell iştiraki KKTCell Kuzey Kıbrıs Türk Cumhuriyeti Telekomünikasyon Dairesi ile gelir paylaşımı anlaşması çerçevesinde faaliyet göstermektedir. Turkcell'in Ukrayna'da \%100 hissesine sahip olduğu Lifecell şirketi Şubat 2005 'de mobil iletişim hizmeti vermeye başladı. Belarus'ta ise Turkcell, BeST'in hisselerinin \%80'ini Belarus Cumhuriyet Devlet Varlik Komitesi'nden 2008'de satın almıştı. 2011 yılından beri Almanya'da Turkcell Europe markasıyla bulunan Turkcell, Deutsche Telekom'un iştiraki ile yaptı̆̆ pazarlama işbirliği ile Almanya'daki faaliyetlerine devam etmektedir (www.turkcell.com.tr). 
Tablo 5: Turkcell EVA ve Marka Rolü Hesaplaması (TL)*

\begin{tabular}{|c|c|c|c|c|c|}
\hline & 2013 & 2014 & 2015 & 2016 & 2017 \\
\hline $\begin{array}{l}\text { Net Faaliyet Kârı } \\
\text { (FVÖK) }\end{array}$ & 2.863 .048 .000 & 2.443 .344 .000 & 3.400 .659 .000 & 3.450 .746 .000 & 3.745 .603 .000 \\
\hline $\begin{array}{l}\text { Vergi } \quad-20 \% \\
\text { (Düzeltilmiş Vergi) }\end{array}$ & 572.609 .600 & 488.668 .800 & 680.131 .800 & 690.149 .200 & 749.120 .600 \\
\hline VSNFK (NOPAT) & 2.290 .438 .400 & 1.954 .675 .200 & 2.720 .527 .200 & 2.760 .596 .800 & 2.996 .482 .400 \\
\hline Dönen Varlıklar & 11.643 .420 .000 & 13.307.712.000 & 8.794 .857 .000 & 13.350 .846 .000 & 14.069.106.000 \\
\hline $\begin{array}{ll}\text { Kısa } & \text { Vadeli } \\
\text { Yükümlülük } & \end{array}$ & 4.311 .005 .000 & 4.991 .169 .000 & 6.304 .417 .000 & 7.358 .858 .000 & 9.223 .843 .000 \\
\hline $\begin{array}{ll}\text { Uzun } & \text { Vadeli } \\
\text { Yükümlülük } & \end{array}$ & 2.233 .812 .000 & 1.988 .390 .000 & 5.480 .552 .000 & 8.172 .903 .000 & 9.713 .538 .000 \\
\hline Borçlar Toplamı & 6.544 .817 .000 & 6.979 .559 .000 & 11.784 .969 .000 & 15.531 .761 .000 & 18.937.381.000 \\
\hline Özsermaye & 14.710 .802 .000 & 16.688 .758 .000 & 14.399 .254 .000 & 16.068.397.000 & 15.045 .088 .000 \\
\hline Pasif Toplamı & 21.255 .619 .000 & 23.668.317.000 & 26.184 .223 .000 & 31.600 .158 .000 & 33.982 .469 .000 \\
\hline Borçların Ağırlığı(wi) & 0,30790997 & 0,29489038 & 0,450079004 & 0,491508967 & 0,557269132 \\
\hline $\begin{array}{l}\text { Borcun Vergiden } \\
\text { Sonraki Maliyeti (ki) }\end{array}$ & 0,1412 & 0,1637 & 0,1512 & 0,1637 & 0,1512 \\
\hline wi*ki & 0,043476888 & 0,048273555 & 0,068051945 & 0,080460018 & 0,084259093 \\
\hline $\begin{array}{l}\text { Özsermaye } \\
\text { (we) }\end{array}$ & 0,69209003 & 0,70510962 & 0,549920996 & 0,508491033 & 0,442730868 \\
\hline $\begin{array}{l}\text { Özsermaye Maliyeti } \\
\text { (ke) }\end{array}$ & 0,131465 & 0,131515 & 0,131515 & 0,13156 & 0,131555 \\
\hline we*ke & 0,090985616 & 0,092732492 & 0,07232286 & 0,06689708 & 0,058243459 \\
\hline AOSM & 0,134462504 & 0,141006047 & 0,140374805 & 0,147357098 & 0,142502552 \\
\hline Net İşletme Sermayesi & 7.332 .415 .000 & 8.316 .543 .000 & 2.490 .440 .000 & 5.991 .988 .000 & 4.845 .263 .000 \\
\hline Duran Varlıklar & 9.612 .199 .000 & 10.360 .605 .000 & 17.389 .366 .000 & 18.249.312.000 & 19.913.363.000 \\
\hline Yatırılan Sermaye & 16.944 .614 .000 & 18.677.148.000 & 19.879.806.000 & 24.241 .300 .000 & 24.758 .626 .000 \\
\hline $\begin{array}{l}\text { Sermaye Maliyeti } \\
\text { (YS*AOSM) }\end{array}$ & 1.944 .498 .703 & 2.389.293.036 & 2.621 .801 .012 & 2.929 .430 .525 & 3.454 .447 .116 \\
\hline $\begin{array}{ll}\text { Ekonomik } & \text { Katma } \\
\text { Değer (EVA) } & \end{array}$ & 345.939 .697 & -434.617 .836 & 98.726 .188 & -168.833 .725 & -457.964 .716 \\
\hline Satış gelirleri & 11.407 .887 .000 & 12.043.587.000 & 12.769 .415 .000 & 14.100 .863 .000 & 17.026.401.000 \\
\hline Faaliyet Karı & 2.863 .048 .000 & 3.179 .108 .000 & 3.400 .659 .000 & 3.450 .746 .000 & 3.745 .603 .000 \\
\hline Marka Rolü (RBI)** & $25,10 \%$ & $26,40 \%$ & $26,63 \%$ & $24,47 \%$ & $22,00 \%$ \\
\hline EVA*RBI & $86.820 .807,13$ & $-114.724 .711,2$ & 26.292.050,18 & $-41.316 .783,23$ & $-100.746 .717,7$ \\
\hline
\end{tabular}

* Tablodaki şirket bilanço ve gelirlerine ait veriler Kamuyu Aydınlatma Platformu'ndan alınmıştır.

** Faaliyet Karı/Satı̧̧ Gelirleri 
Aşağıdaki tabloda Turkcell’in yedi kriter çerçevesinde değerlendirilen ve toplamı verilen marka gücü skorları görülmektedir.

Tablo 7: Turkcell Marka Gücü Skoru

\begin{tabular}{ccccccc}
\hline Liderlik & İstikrar & $\begin{array}{c}\text { Coğrafi } \\
\text { Yayılım }\end{array}$ & $\begin{array}{c}\text { Pazarlama } \\
\text { Desteği }\end{array}$ & Korunma & Pazar & Trend \\
$\mathbf{2 0 , 7 5}$ & 11,75 & 17,5 & 10 & 4,5 & 9 & 9,25 \\
& & Ískonto Orant $-\boldsymbol{r} \mathbf{7 \%}$ & & Toplam & 82,75 \\
\hline
\end{tabular}

Not: Marka gücü skorları anket yoluyla elde edilen veriler ile toplanmıştır.

Yukarıdaki tablodaki değerlerden elde edilen toplam marka gücü skoru 82.75 'tir. Bu marka gücü skoruna karşılık gelen iskonto oranı \%7'dır.

\subsubsection{Türk Hava Yolları}

Türk Hava Yolları 1933 yılında kurulan şirketin ana faaliyet konusu yurtiçi ve yurt dışında yolcu ve kargo hava taşımacılığı yapmaktır. Şirketin ortaklık yapısı \%49 T.C. Başbakanlık Özelleştirme İdaresi Başkanlığı'na ait ve \%51 halka açıktır. Şirketin sahibi veya ortak olduğu markalar Türk Hava Yolları, Anadolu Jet, SunExpress, Turkish DO\&CO, TGS Yer Hizmetleri, THY OPET Havacılık Yakıtları, Uçak Koltuk Üretimi, TCI Kabin İçi Sistemleri, TEC-Turkish Engine Center, Goodrich T.T. Servis Merkezi, Turkbine Teknik Gaz Türbinleri Bakım Onarım, Vergi İade Aracılık, Kuzey Tankercilik, Güney Tankercilik, Turkishairlines Flight Academy'dir (www.turkishairlines.com). 
Tablo 8: THY EVA ve Marka Rolü Hesaplaması (TL)*

\begin{tabular}{|c|c|c|c|c|c|}
\hline & 2013 & 2014 & 2015 & 2016 & 2017 \\
\hline $\begin{array}{l}\text { Net Faaliyet Kârı } \\
\text { (FVÖK) }\end{array}$ & 1.226 .125 .748 & 1.443 .000 .000 & 2.486 .000 .000 & -865.000 .000 & 3.568 .000 .000 \\
\hline $\begin{array}{l}\text { Vergi -20\% } \\
\text { (Düzeltilmiş Vergi) }\end{array}$ & $245.225 .149,6$ & 288.600 .000 & 497.200 .000 & -173.000 .000 & 713.600 .000 \\
\hline VSNFK (NOPAT) & 980.900 .598 & 1.154 .400 .000 & 1.988 .800 .000 & -692.000 .000 & 2.854 .400 .000 \\
\hline Dönen Varlıklar & 4.535 .535 .069 & 6.564 .848 .184 & 9.148 .000 .000 & 5.159 .000 .000 & 7.132 .000 .000 \\
\hline $\begin{array}{ll}\text { Kısa } & \text { Vadeli } \\
\text { Yükümlülük } & \end{array}$ & 6.652 .755 .831 & 8.505.344.748 & 11.248 .000 .000 & 12.673 .000 .000 & 13.699.000.000 \\
\hline $\begin{array}{l}\text { Uzun } \\
\text { Yükümlülük }\end{array}$ & 11.786 .831 .631 & 14.215 .859 .184 & 22.300 .000 .000 & 31.343 .000 .000 & 32.267 .000 .000 \\
\hline Borçlar Toplamı & 18.439 .587 .462 & 22.721 .203 .932 & 33.548 .000 .000 & 44.016 .000 .000 & 45.966 .000 .000 \\
\hline Özsermaye & 6.962 .490 .356 & 9.154 .403 .130 & 14.090 .000 .000 & 17.899 .000 .000 & 20.171 .000 .000 \\
\hline Pasif Toplamı & 25.402 .077 .818 & 31.875 .607 .062 & 47.638 .000 .000 & 65.074 .000 .000 & 68.647 .000 .000 \\
\hline Borçların Ağırlığı(wi) & 0,725908628 & 0,712808509 & 0,704227717 & 0,676399176 & 0,669599546 \\
\hline $\begin{array}{l}\text { Borcun Vergiden } \\
\text { Sonraki Maliyeti (ki) }\end{array}$ & 0,0899 & 0,092825 & 0,116338462 & 0,103916667 & 0,149983333 \\
\hline$w i * k i$ & 0,065259186 & 0,06616645 & 0,081928769 & 0,070289148 & 0,100428772 \\
\hline Özsermaye Ağırlığı (we) & 0,274091372 & 0,287191491 & 0,295772283 & 0,27505609 & 0,293836584 \\
\hline $\begin{array}{l}\text { Özsermaye Maliyeti } \\
\text { (ke) }\end{array}$ & 0,082365 & 0,09162 & 0,092133462 & 0,099711667 & 0,108278333 \\
\hline we*ke & 0,022575536 & 0,026312484 & 0,027250524 & 0,027426301 & 0,031816136 \\
\hline AOSM & 0,087834722 & 0,092478934 & 0,109179293 & 0,097715449 & 0,132244907 \\
\hline Net İşletme Sermayesi & -2.117 .220 .762 & -1.940 .496 .564 & -2.100 .000 .000 & -7.514 .000 .000 & -6.567 .000 .000 \\
\hline Duran Varlıklar & 20.866 .542 .749 & 25.310 .758 .878 & 38.490 .000 .000 & 52.401 .000 .000 & 54.948 .000 .000 \\
\hline Yatırılan Sermaye & 18.749.321.987 & 23.370 .262 .314 & 36.390 .000 .000 & 44.887 .000 .000 & 48.381 .000 .000 \\
\hline $\begin{array}{l}\text { Sermaye } \\
\text { (YS*AOSM) }\end{array}$ & 1.647 .597 .708 & 1.733.917.315 & 2.551 .548 .727 & 3.555 .865 .185 & 5.936.077.161 \\
\hline $\begin{array}{l}\text { Ekonomik } \\
\text { Değer (EVA) }\end{array}$ & -666.697 .110 & -579.517 .315 & -562.748 .727 & -4.247 .865 .185 & -3.081 .677 .161 \\
\hline Satış gelirleri & 18.776.784.325 & 24.158 .000 .000 & 28.752 .000 .000 & 29.468 .000 .000 & 39.779.000.000 \\
\hline Faaliyet Karı & 1.226 .125 .748 & 1.443 .000 .000 & 2.486 .000 .000 & -865.000 .000 & 3.568 .000 .000 \\
\hline Marka Rolü (RBI)*** & $6,53 \%$ & $5,97 \%$ & $8,65 \%$ & $-2,94 \%$ & $8,97 \%$ \\
\hline EVA*RBI & $-43.535 .382,76$ & $-34.615 .592,6$ & $-48.657 .252,89$ & $-124.691 .305,3$ & $-276.412 .783,4$ \\
\hline
\end{tabular}

* Tablodaki şirket bilanço ve gelirlerine ait veriler Kamuyu Aydınlatma Platformu'ndan alınmıştır.

** Faaliyet Karı/Satı̧̧ Gelirleri 
Aşağıdaki tabloda THY'nin yedi kriter çerçevesinde değerlendirilen ve toplamı verilen marka gücü skorları görülmektedir.

Tablo 9: THY Marka Gücü Skoru*

\begin{tabular}{ccccccc}
\hline Liderlik & İstikrar & $\begin{array}{c}\text { Coğrafi } \\
\text { Yayılım }\end{array}$ & $\begin{array}{c}\text { Pazarlama } \\
\text { Desteği }\end{array}$ & Korunma & Pazar & Trend \\
$\mathbf{2 1 , 7 5}$ & 11,75 & 23,25 & 10 & 5 & 9,75 & 8,75 \\
& & İskonto Oranı $-\mathbf{r} \quad \mathbf{5 , 5 \%}$ & & Toplam & 90,25 \\
\hline
\end{tabular}

Not: Marka gücü skorları anket yoluyla elde edilen veriler ile toplanmıştır.

Yukarıdaki tablodaki değerlerden elde edilen toplam marka gücü skoru 82.75 'tir. $\mathrm{Bu}$ marka gücü skoruna karşılık gelen iskonto oranı \%5,5'dir.

\subsubsection{Arçelik}

1955 y1lında kurulmuş olan Arçelik dayanıklı tüketim, tüketici elektroniği, küçük ev aletleri ve mutfak aksesuarları alanlarında üretim, pazarlama, satış ve satış sonrası müşteri hizmetleri faaliyetlerini yapan bir şirkettir. Şirketin \%57 Koç Grubu'na, \%25 Burla Grubu'na aittir, \%18'i halka açıktır. Şirketin dünyada 7 ülkede üretim tesisi bulunmaktadır ve 11 markasıyla (Arçelik, Beko, Grundig, Blomberg, Elektrabregenz, Arctic, Leisure, Flavel, Defy, Altus ve Dawlance) 145 'ten fazla ülkede hizmet vermektedir (www.arcelik.com.tr). 
Tablo 10: Arçelik EVA ve Marka Rolü Hesaplaması (TL)*

\begin{tabular}{|c|c|c|c|c|c|}
\hline & 2013 & 2014 & 2015 & 2016 & 2017 \\
\hline $\begin{array}{l}\text { Net Faaliyet Kârı } \\
\text { (FVÖK) }\end{array}$ & 1.122 .526 .000 & 968.789 .000 & 1.282 .757 .000 & 1.498 .071 .000 & 1.711 .831 .000 \\
\hline $\begin{array}{c}\text { Vergi -20\% } \\
\text { (Düzeltilmiş Vergi) }\end{array}$ & 224.505 .200 & 193.757 .800 & 256.551 .400 & 299.614 .200 & 342.366 .200 \\
\hline VSNFK (NOPAT) & 898.020 .800 & 775.031 .200 & 1.026 .205 .600 & 1.198 .456 .800 & 1.369 .464 .800 \\
\hline Dönen Varlıklar & 7.659 .118 .000 & 8.471 .757 .000 & 9.406 .252 .000 & 10.973 .872 .000 & 13.609 .776 .000 \\
\hline $\begin{array}{c}\text { Kısa Vadeli } \\
\text { Yükümlülük }\end{array}$ & 4.091 .143 .000 & 4.430 .803 .000 & 5.236 .297 .000 & 6.606 .088 .000 & 8.403 .020 .000 \\
\hline $\begin{array}{l}\text { Uzun Vadeli } \\
\text { Yükümlülük }\end{array}$ & 3.181 .017 .000 & 3.565 .504 .000 & 3.826 .374 .000 & 4.298 .703 .000 & 5.118 .398 .000 \\
\hline Borçlar Toplamı & 7.272 .160 .000 & 7.996.307.000 & 9.062 .671 .000 & 10.904 .791 .000 & 13.521 .418 .000 \\
\hline Özsermaye & 4.138 .756 .000 & 4.398 .698 .000 & 4.675 .837 .000 & 6.004 .577 .000 & 6.915 .077 .000 \\
\hline Pasif Toplamı & $\begin{array}{c}11.410 .916 .00 \\
0\end{array}$ & $\begin{array}{c}12.395 .005 .00 \\
0\end{array}$ & 13.738.508.000 & 16.909 .368 .000 & 20.436 .495 .000 \\
\hline Borçların Ağırlığı(wi) & 0,637298531 & 0,645123338 & 0,659654673 & 0,644896427 & 0,661630969 \\
\hline $\begin{array}{c}\text { Borcun Vergiden } \\
\text { Sonraki Maliyeti (ki) }\end{array}$ & 0,1019 & 0,110825 & 0,111338462 & 0,118916667 & 0,127483333 \\
\hline wi*ki & 0,06494072 & 0,071495794 & 0,073444936 & 0,076688933 & 0,084346921 \\
\hline Özsermaye Ağırlığı (we) & 0,362701469 & 0,354876662 & 0,340345327 & 0,355103573 & 0,338369031 \\
\hline Özsermaye Maliyeti (ke) & 0,082575 & 0,09111 & 0,091623462 & 0,099366667 & 0,107968333 \\
\hline we*ke & 0,029950074 & 0,032332813 & 0,031183617 & 0,035285458 & 0,03653314 \\
\hline AOSM & 0,094890794 & 0,103828607 & 0,104628553 & 0,111974392 & 0,120880062 \\
\hline Net İşletme Sermayesi & 3.567 .975 .000 & 4.040 .954 .000 & 4.169 .955 .000 & 4.367.784.000 & 5.206 .756 .000 \\
\hline Duran Varlıklar & 3.751 .798 .000 & 3.923 .248 .000 & 4.332 .256 .000 & 5.935 .496 .000 & 6.826 .719 .000 \\
\hline Yatırılan Sermaye & 7.319.773.000 & 7.964 .202 .000 & 8.502 .211 .000 & 10.303 .280 .000 & 12.033 .475 .000 \\
\hline $\begin{array}{l}\text { Sermaye Maliyeti } \\
(\text { YS*AOSM) }\end{array}$ & $596.590 .663,4$ & $760.001 .831,3$ & $833.282 .934,4$ & $952.029 .905,7$ & 1.245 .461 .122 \\
\hline $\begin{array}{c}\text { Ekonomik Katma Değer } \\
\text { (EVA) }\end{array}$ & 301.430 .137 & 15.029 .369 & 192.922 .666 & 246.426 .894 & 124.003 .678 \\
\hline Satış gelirleri & $\begin{array}{c}11.097 .711 .00 \\
0\end{array}$ & $\begin{array}{c}12.514 .033 .00 \\
0\end{array}$ & 14.166.100.000 & 16.096 .172 .000 & 20.840 .613 .000 \\
\hline Faaliyet Karı & 1.122 .526 .000 & 968.789 .000 & 1.282 .757 .000 & 1.498 .071 .000 & 1.711 .831 .000 \\
\hline Marka Rolü (RBI)** & $10,11 \%$ & $7,74 \%$ & $9,06 \%$ & $9,31 \%$ & $8,21 \%$ \\
\hline EVA*RBI & $30.489 .455,48$ & $1.163 .516,757$ & $17.469 .374,06$ & $22.934 .955,21$ & $10.185 .561,23$ \\
\hline
\end{tabular}

* Tablodaki şirket bilanço ve gelirlerine ait veriler Kamuyu Aydınlatma Platformu’ndan alınmıştır.

** Faaliyet Karı/Satı̧ Gelirleri 
Aşağıdaki tabloda Arçelik'in yedi kriter çerçevesinde değerlendirilen ve toplamı verilen marka gücü skorları görülmektedir.

Tablo 11: Arçelik Marka Gücü Skoru

\begin{tabular}{ccccccc}
\hline Liderlik & İstikrar & $\begin{array}{c}\text { Coğrafi } \\
\text { Yayılım }\end{array}$ & $\begin{array}{c}\text { Pazarlama } \\
\text { Desteği }\end{array}$ & Korunma & Pazar & Trend \\
$\mathbf{1 3}$ & 10,5 & 13,75 & 7,75 & 4,75 & 9,5 & 6,5 \\
& & İskonto Oranı $-\mathbf{r} \mathbf{7 \%}$ & Toplam & 65,75 \\
\hline
\end{tabular}

Not: Marka gücü skorları anket yoluyla elde edilen veriler ile toplanmıştır.

Yukarıdaki tablodaki değerlerden elde edilen toplam marka gücü skoru 65.75 'tir. Bu marka gücü skoruna karşıllk gelen iskonto oranı \%7'dir.

\subsection{Marka Değer Sıralamaları}

Interbrand indirgenmiş nakit akım yöntemine göre yapılan marka değerleme hesaplamalarına ilişkin bulgular aşağıdaki tabloda görülmektedir. Türk Telekom ve Turkcell'in marka değeri hesaplanırken ekonomik katma değer modeline göre karının ekside olduğu yıllar formüle dahil edilmemiştir. Ekonomik katma değer modeline göre Türk Hava Yolları'nın son beş yılda karı ekside olduğundan marka değeri hesaplanamamıştır.

Tablo 12: Marka Değer Sıralamaları

\begin{tabular}{cc} 
Marka & Marka Değeri (TL) \\
Türk Telekom & $641.132 .190,9$ \\
Turkcell & $104.105 .436,1$ \\
Arçelik & $68.530 .423,66$ \\
\hline
\end{tabular}

Yukarıdaki marka değeri hesaplaması önceki sayfalarda yer alan her bir şirkete ait finansal verilerle hesaplanmış son beş yıllık ekonomik katma değerin, marka rolü endeksinin ve iskonto oranlarının kullanıldığı Interbrand marka değerleme formülüne göre yapılmıştır. Markaların Interbrand indirgenmiş nakit akım yöntemine göre hesaplanan değerleri sırasıyla Türk Telekom 641.132.190, TL, Turkcell 104.105.436,1 TL, Arçelik 68.530.423,66 TL'dir. BrandFinance Turkey 2017 araştırmasında markaların değerleri sırasıyla THY 2.042 milyon Dolar, Türk Telekom 1.907 milyon Dolar, Turkcell 1.841 Dolar, Arçelik 1.258 milyon Dolar olarak hesaplanmıştır. 


\section{SONUÇ}

Günümüzde marka olmak firmalar açısından önem arz etmektedir. Firmalar marka olmak için soyut varlıklarına yatırım yapmaktadırlar. $\mathrm{Bu}$ yatırımların performansa etkisini ölçmek amacıyla çeşitli finansal değerleme yöntemleri kullanılmaktadır. Marka değerleme bu finansal yöntemlerden birisidir. Marka değeri tüketicilerin bakış açısıyla yapılabilirken finans bakış açısıyla firmanın soyut varlıklarının kazançları içerisindeki rolünün belirlenmesi yoluyla da yapılabilmektedir. Ayrıca her iki bakış açısını birlikte kullanan karma modeller de bulunmaktadır. Bu çalışmada bu şekildeki karma modellerden Interbrand indirgenmiş nakit akım yöntemiyle Türk markalarına değerleme hesaplaması yapılmıştır.

Interbrand indirgenmiş nakit akım yöntemiyle yapılan marka değerlemesi sonucunda Türk markalarının değeri daha önce Brand Finance tarafından yapılan değerlemeden daha düşük hesaplanmıştır. Değerlendirmeye alınan Türk markaları içerisinde en değerli marka 641 milyon TL ile Türk Telekom iken, Turkcell 104 milyon TL ile ikinci, Arçelik 68 milyon TL ile üçüncüdür.

Marka değeri hesaplamasında hesaplanan marka rolü endekslerinin sektör ortalamalarının altında olduğu görülmüştür. Son beş yılın ortalama marka rolü endeksleri, Turkcell için \%24,92 (S.O.:\%20.2)1, Türk Telekom için \%19.18 (S.O.: \%13.2), Arçelik için $\% 8,89$ (S.O.:\%7), THY için \%5,44 (S.O.: 8.6)'tür. Marka gücü skorları ise, THY 90,25, Turkcell 82,75 , Türk Telekom 71,25, Arçelik 65,75'tir. Markalı ürünlerden elde edilen satış gelirlerinin kara etkisi olarak ifade edilen ve faaliyet marjına eşit kabul edilen marka rolü endeksi Turkcell için yüksektir. Dünyanın en değerli markalarından Apple'ın 2017 faaliyet marjının \%26.87² olduğu göz önünde bulundurulduğunda, Turkcell'in bu konuda oldukça başarılı olduğu söylenebilir. Öte yandan Türk Hava Yolları'nın marka gücü skoru en yüksek olan şirkettir. Bunun nedeni faaliyet gösterdiği sektördeki ilk ve en eski olmasından edindiği ayrıcalıklı konumu ve yoğun bir şekilde reklam, tanıtım gibi tutundurma faaliyetleri çabaları olduğu düşünülmektedir.

Sonuç olarak bu çalışmayla, Türk markaları üzerinde marka değerlemesi hesaplaması yapılarak marka değerini nelerin etkilediği belirlenmeye çalışılmıştır. Bu çalışmanın katkısı Türk markalarının değerlerine göre sıralamasının yapılarak değerlemede önemli olan boyutların ortaya çıkarılmasıdır. Böylelikle bu alanda yapılacak araştırmalara temel kaynak teşkil etmesi düşünülmektedir. Bu çalışmanın belirli bazı sınırlandırmaları bulunmaktadır. Bunlardan birincisi Interbrand yönteminde tüketicilerin değerlendirilmesine yer verilmekteyken bu çalışmada finansal verilerden yararlanılmasıdır. İkincisi araştırma şirketleri tarafından ileride yapılacak çalışmalar için marka değeri hesaplamasında marka gücü skorunun belirlenmesinde daha fazla faktörün ele alınmasıdır. Ayrıca marka gücü skorunun belirlenmesinde görüşlerine başvurulan akademisyenlerin yanlılık / yanılma payları da bulunabilmektedir.

Marka değerleme, firmaların sahip oldukları soyut varlıkları arttıkça ve paralel olarak işletme içindeki konumları tartışılmaya başladıkça daha da önemli bir konu haline gelmektedir. $\mathrm{Bu}$ açıdan bir pazarlama şirketi olan Interbrand, markanın sadece finansal değeri değil firma içindeki konumuna da rehberlik etmektedir. Bu şirketin geliştirdiği model öncelikle pazar bölümünün belirlenmesi gibi pazarlama yönlü bakışla markanın işletme içindeki konumu ortaya çıkarılmaktadır. Böylelikle işletmenin faaliyet gösterdiği ana pazarı ve rakiplerine göre finansal

\footnotetext{
1 Sektör ortalamalar1 https://insight.factset.com/sp-500-reporting-record-high-net-profit-margin-for-q1-2018 adresinden elde edilmiştir. Erişim: 14.11.2018

2 Apple Operating Margin 2006-2018, https://www.macrotrends.net/stocks/charts/AAPL/apple/operating-margin, Erişim: 14.11.2018
} 
hesaplar yapılabilmektedir. Daha sonra finansal hesaplamalarla markanın mevcut değer yaratma durumu belirlenmektedir. $\mathrm{Bu}$ nedenle Interbrand yöntemiyle Türk markalarının incelenmesi gereği duyulmuştur. Gelecekte yapılacak çalışmalar için özellikle pazarlama araştırmacılarının işletme soyut varlıklarını değerlemede tüketici yönlü değişkenlerin geliştirilmesi önerilmektedir. Marka değerlemede öznellik en önemli sorunlardan biri olarak görülmektedir. Bunun üstesinden gelebilmek için markalara yönelik tüketici algı, tutum ve davranışlarının tutarlı bir şekilde incelenmesi ve finansal analiz yöntemleriyle sentezlenmesinin bu alana önemli katkı sağlayacağı düşünülmektedir.

\section{KAYNAKÇA}

Aaker, D. A. (1991). Managing Brand Equity: Capitalizing on the Value of a Brand Name, New York. Google Scholar.

Aydın, G.(2009). Tüketici Temelli Marka Değerinin Firmaların Finansal Performansı Üzerine Etkisi: Türkiye'de Bir Çalışma. İstanbul Teknik Üniversitesi Fen Bilimleri Enstitüsü, İşletme Mühendisliği Anabilim Dalı, Doktora Tezi, İstanbul.

Barth, M. E., Clement, M. B., Foster, G., \& Kasznik, R. (1998). Brand Values and Capital Market Valuation. Review of Accounting Studies, 3(1-2), 41-68.

Berry, L. (2000). Cultivating Service Brand Equity. Journal of the Academy of Marketing Science, 28, 1, pp. 128-137.

Blackston, M. (1992). Building Brand Equity by Managing the Brand's Relationships. Journal of Advertising Research, 32, 3, pp. 79-83.

Burmann, C., Jost-Benz, M. \& Riley, N. (2009) Towards an Identity-Based Brand Equity Model. Journal of Business Research, 62, 390-397.

Christodoulides, G., de Chernatony, L. (2010). Consumer-Based Brand Equity Conceptualisation and Measurement: A Literature Review. International Journal of Market Research. 2010, Vol. 52 Issue 1, p43-66. 24p.

De Chernatony, L., McDonald, M., \& Wallace, E. (2011). Creating Powerful Brands. Butterworth-Heinemann,

Hatipoğlu, Mercan (2011). Firma Değerlemesi Ve İmkb’de Enerji Sektöründe Uygulaması. Çankırı Karatekin Üniversitesi Sosyal Bilimler Enstitüsü İşletme Anabilim Dalı, Yüksek Lisans Tezi

Karataş, Özlem Nilüfer (2014). Marka Değerleme Modelleri: Bist - Bankacılık Sektöründe Bir Uygulama, T.C. Süleyman Demirel Üniversitesi Sosyal Bilimler Enstitüsü İşletme Anabilim Dalı, Doktora Tezi.

KAYA, Yusuf (2002). Marka Değerleme Metotları ve Bu Metotların Kullanımında Sermaye Piyasası Mevzuatı Açısından Çıkabilecek Sorunlar Sermaye Piyasası Kurulu Denetleme Dairesi Yeterlik Etüdü, İstanbul.

Keller, K. L. (1993). Conceptualizing, Measuring, and Managing Customer-Based Brand Equity. The Journal of Marketing, 1-22.

Koca, B.B. (2015). Marka Değerleme ve Spor Endüstrisinde Örnek Uygulama Çalışması: Türk Telekom Örneği. Gazi Üniversitesi, Sosyal Bilimler Enstitüsü, İşletme Anabilim Dalı, Yüksek Lisans Tezi, Ankara.

Kocak, A., Abimbola, T., \& Özer, A. (2007). Consumer brand equity in a cross-cultural replication: An evaluation of a scale. Journal of Marketing Management, 23(1-2), 157-173.

Koçak, A. , Abimbola, T. \& Özer, A. (2007). Consumer Brand Equity in a Cross-cultural Replication: An Evaluation of a Scale. Journal of Marketing Management, 23:1-2, 157-173, DOI: 10.1362/026725707X178611.

Leslie De Chernatony, Malcolm McDonald, Elaine Wallace (2011). Creating Powerful Brands, ISBN 1856178498, 9781856178495, Routledge.

Özsevinç, T. (2013). Marka Değerleme Yöntemleri ve Küresel Marka Değeri: Şarkıcı, Doktor Ve Politikacı Örnekleri. TOBB Ekonomi ve Teknoloji Üniversitesi Sosyal Bilimler Enstitüsü İşletme Anabilim Dalı, Yüksek Lisans Tezi, Ankara.

Pinar, M., Girard, T., Eser, Z. (2012). Consumer-Based Brand Equity İn Banking İndustry: A Comparison Of Local And Global Banks İn Turkey. International Journal of Bank Marketing, Vol. 30 Iss: 5 pp. 359 - 375

Salinas, G. (2011). The International Brand Valuation Manual: A complete overview and analysis of brand valuation techniques, methodologies and applications. John Wiley \& Sons. 
Wasserman, B. (2015). Valuation of Intangible Assets: Should Brand Equity Be Accounted for on the Balance Sheet?.

Zambon, S., \& Monciardini, D. (2015). Intellectual Capital and Innovation. A guideline for future research. Journal of Innovation Economics \& Management, (2), 13-26.

Zengin, B., \& Güngördü, A. (2015). Marka Değerinin Hesaplanması Üzerine Ampirik Bir Çalışma: Finans Ve Pazarlama Boyutu. Gazi Üniversitesi İktisadi ve İdari Bilimler Fakültesi Dergisi, 17(2), 282-298. 